\title{
FOR STUDY, FUTURE CAREER AND RELIGIOUS PRACTICES: FEMALE SANTRIS' MOTIVATIONS FOR LEARNING ENGLISH
}

\author{
Euis Rina Mulyani \\ euisrinamulyani@gmail.com \\ English Education Program, Faculty of Language Education, IKIP Siliwangi, Cimahi- \\ Indonesia
}

\begin{abstract}
This paper reports a survey study investigating motivation for learning English of Indonesian female students. The participants were 200 female students of a senior high school of a pesantren in West Java, Indonesia who participated voluntarily. The data was gained through close-ended and open-ended questionnaires. The close-ended questionnaire was adapted from Choosri's (2011) instrument. The data from the closeended questionnaire was analyzed quantitatively involving average score and percentage using Microsoft Excel statistical package; whereas the data from the openended questionnaire was analyzed qualitatively using Miles and Huberman's (1994) framework of qualitative data analysis. Based on the data, it was found that the students' motivations were more instrumental than integrative, especially to continue their study to the university level, to broaden their knowledge, achieve good grade/score, and achieve better career. It was also revealed that religious motivation of learning English existed among the students: expecting to be future pendakwah 'Muslim preacher' and making silaturahmi (knowing more and communicating) with English speaking Muslims.
\end{abstract}

Keywords: Instrumental motivation, Integrative motivation, Motivation of learning English, Religious motivation,

\section{Sari}

Artikel ini melaporkan penelitian survey tentang motivasi belajar Bahasa Inggris siswa putri di sekolah setingkat SMA. Penelitian ini menggunakan desain survey. Partisipannya adalah 200 orang siswa putri di sebuah sekolah Madrasah Aliyah (MA) yang berada di bawah naungan sebuah pesantren di provinsi Jawa Barat, Indonesia. Para partisipan berpartisapasi dalam penelitian ini secara sukarela. Instrument penelitiannya adalah kuisioner tertutup dan terbuka. Kuisioner tertutup diadaptasi dari instrumen Choosri (2011). Data yang didapatkan dari kuisioner tertutup dianalisa secara kuantitatif yang meliputi nilai rata-rata dan persentase dengan menggunakan Microsoft Excel; sedangkan data dari kuisioner terbuka dianalisa dengan menggunakan konsep analisis 
data kualitatif Miles dan Huberman (1994). Data yang telah dianalisa menunjukkan bahwa motivasi para siswa putri di sekolah tersebut dalam belajar belajar Bahasa Inggris lebih bersifat instrumental daripada integrative, terutama motivasi untuk melanjutkan studi ke tingkat unversitas, untuk memperluas pengetahuan, mendapatkan nilai yang baik, serta untuk mendapatkan pekerjaan yang lebih baik. Selain itu, ditemukan pula bahwa di antara mereka ada memiliki motivasi yang bersifat religious, yaitu ingin menjadi pendakwah dan bersilaturahmi dengan Muslim yang berbahasa Inggris.

Kata Kunci: motivasi belajar Bahasa Inggris, motivasi instrumental, motivasi integrative, motivasi religious

Received 2020-09-02 accepted 2020-09-30 published 2020-09-30

APA Citation: Mulyani, E.R. (2020). FOR STUDY, FUTURE CAREER AND RELIGIOUS PRACTICES: FEMALE SANTRIS' MOTIVATIONS FOR LEARNING ENGLISH. Research and Innovation in Language Learning 3(3), pp. 257-260 http://dx.doi.org/10.33603/rill.v3i3.4213

\section{This Study}

Motivation is an important factor since it can trigger learners to achieve successfulness in a language learning. Students with instrumental motivations take benefit from language learning to reach practical advantages like to get a job and to continue to study to a higher level. In contrast, students with integrative motivation learn a language in order to know more about and to communicate with the target-language communities. Some studies relating to students' motivation in learning English have been found. However, previous works more focused on students at university level and paid less attention to high school students. In addition, studies on female students' motivation of learning English, particularly in Muslim schools, have not been found yet. Therefore, the present study is interested in investigating female students' motivation of learning English; particularly those who live in a pesantren. A pesantren is Indonesian Muslimcommunity-based education institution consisting of Kyai (the top leader of a pesantren), ustads 'teachers', santris 'students', Islamic studies, students' dormitory, a mosque', and classrooms.

The questionnaires with open-ended and close-ended questions were employed. The close-ended questionnaire was adapted from Choosri's (2011) instrument. The participants of this study were 200 female santris (students of a pesantren) who were 
studying at the pesantren's senior high school. They participated in this research voluntarily. Finally, the data from the close-ended questionnaire was analyzed quantitatively involving average score and frequency; whereas the data from openended questionnaire was analyzed using Miles and Huberman's (1994) framework of qualitative data analysis.

\section{Findings}

The finding suggests that majority students were triggered to study English through the instrumental motivation. The students' instrumental motivations are mainly to achieve their desires: (1) to further their study to the college level (higher education), (2) to broaden their knowledge, (3) to get good grade/score, and (4) to get good income. In other words, most students' primary instrumental orientations of learning English focused on study; whereas their secondary motivations were geared towards a decent career. In short, in learning English, most students preferred instrumental motivation to integrative one. The finding gives new insights on how seeing santris efforts in their English learning to be religious pendakwah (Muslim preacher) and to have silaturahmi (to know better and communicate) with their foreign Muslim. The findings also revealed the santries were enthusiastically in their learning vocabularies toward their TOEFL in advanced in the their higher education.

\section{Discussion and conclusion}

The finding of this study is in line with some previous researches such as Hong (2017). Furthermore, the data from the close ended questionnaire was supported by the data gained from the open-ended questionnaire. The students said that they learned English because it can be a tool to make them easier to continue study to university level and get a decent job. This motivation is probably because many Indonesian colleges and workplaces provide entrance tests such as TOEFL. In addition, the present study also finds a unique finding. Based on the data, it is revealed that some of the students' motivations for learning English are religious: to be pendakwah (Muslim preacher) and to have silaturahmi overseas. These motivations is integrative motivation because they desire to know more and communicate with English speaking people (specifically with those who are Muslim). This religious motivation is probably influenced by other 
factors which are not observed in this research. They are probably influenced by their learning context and environment - the pesantren - which highly uphold Islamic values. Some previous studies such as Hayat (2016) Lamb (2007), and Pham and White (2018) have proved that learning context and environment have important roles in shaping types of students' learning motivation. To conclude, the findings portray santris' primary motivations of learning English are for study; the secondary motivation is future profession reasons; and tertiary motivation is for religious practices. Their motivations are believed to be shaped by various factors including the students learning context and environment.

\section{References}

Choosri, C. \& Intharaksa, U. (2011). Relationship between motivation and students learning achievement: a study of the second-year vocational certificate level Hatyai Technical college students. The $3^{\text {rd }}$ International Conference on Humanities and Social Sciences Proceedings. Retrieved from http: //tar.thailis.or.th/bitstream/123456789/665/1/006

Hayat, A.A., Kohoulat, N., Deghdani, M. R., Kojuri, J. \& Amini, M. (2016). Students' perceived Environment and extrinsic and intrinsic motivation. International Journal of Humanities and Cultural Studies, 3(2), 1000-10011.

Hong, Y.C., \& Ganaphaty, M. (2017). To investigate ESL students' instrumental and integrative motivation toward English language learning in a Chinese school in Penang: Case Study. English Language Teaching, 10(9). https://doi.org/ 10.5539/elt.v10n9p17.

Lamb, M. (2007), The impact of School on EFL Learning motivation: an Indonesian case study. Teachers of English to Speakers of Other Languages (TESOL), 4 (4), 757-780.

Miles, M.B., \& Huberman, A.M. (1994). An Expanded sourcebook Qualitative Data Analysis. Sage Publications.

Pham, W.C. \& White, C. (2018). Rural students' motivation for learning English. In Albright, J. (Ed.). English tertiary education in Vietnam. Routledge.

\section{Conflict of Interest}

No conflict of interest was reported.

\section{About author}

Euis Rina Mulyani is a faculty staf at English Education Program, Faculty of Language Education, IKIP Siliwangi, Cimahi-Indonesia. Her research interest is TEFL methodologies. She is reachable at euisrinamulyani@gmail.com

https://orcid.org/0000-0001-7672-3799 